\title{
A Review of Arabicization as a Controversial Issue of Language Planning in the Sudan
}

\author{
Asjad Ahmed Saeed Balla ${ }^{1 \& 2}$ \\ ${ }^{1}$ Prince Sattam University, Al-Aflaj, KSA \\ ${ }^{2}$ Gadarif University, Sudan \\ Correspondence: Asjad Ahmed Saeed Balla, Prince Sattam University, Al-Aflaj, KSA; Gadarif University, Sudan. \\ E-mail: gamar6@hotmail.com
}

Received: March 20, 2017 Accepted: May 2, 2017 Online Published: May 30, 2017

doi:10.5539/ells.v7n2p144 URL: http://doi.org/10.5539/ells.v7n2p144

\begin{abstract}
This paper tries to review the issue of Arabicization through languages policy in the Sudan by tracing the different periods of the ups and downs of this process in its social and political context. Arabization and Arabicization are two terms used to serve two different purposes. Arabization is the official orientation of the (ruling group) towards creating a pro-Arab environment, by adopting Arabic culture, Arabic language in addition to Islam as main features of Arabizing the Sudanese entity. The mechanism towards imposing this Arabization is through the use of Arabic, as the official language the group (government). Arabicization is an influential word in the history of education in Sudan. The Sudan faced two periods of colonialism before Independence, The Turkish and the Condominium (British-Egyptian) Rule. Through all these phases in addition to the Mahdist period between them, many changes and shifts took place in education and accordingly in the Arabicization process. During the Condominium period, the Christian missions tried strongly to separate the South Region from the North Region, and to achieve this goal the government fought against the Arabic language so it would not create a place among the people of the Southern Sudan. But in spite of all the efforts taken by the colonialists, Arabic language found its place as Lingua Franca among most of the Southern Sudan tribes. After independence, the Arabicization process pervaded education. Recently, the salvation revolution also has used Arabicization on a wider range, but Arabicization is still future project. Both Arabization and Arabicization are still controversial issues.
\end{abstract}

Keywords: Sudan, Arabicization, language planning, language policy, Lingua Franca

\section{Introduction}

The word "ta'rib" has got two equivalents in English Arabization and Arabicization. The former concerns the superiority of culture and identity, while the latter deals with superiority of Arabic as a language. The two terms existed as a result of colonialism of the Arab countries such as the British colonized Sudan (Suliman, 2004). Wheeler (1966) defines Arabization as "desire to strengthen the deep rooted traditions of Islam and Arab Civilization and to maintain the bonds between religion and education" (p. 304). Hence all the Arab states got their independence Arab tried to keep their language, religion and identity that was influenced by the colonialism (Suliman, 2004).

Sudan is one of the Arab countries which suffered from colonialism. Arabicization is the main issue in this research paper. Many conferences were held all over the Arab world to implement Arabicization in general and in education in particular. The Syrian government took the initiative to give Arabic an official status in the government offices and in Education. Sudan then tried to implement Arabicization in higher Education.

\section{Arabicization, Language Planning and Language Policy}

Arabicization comes as a result of language planning and language policy. Both are done by governments as both are decision that needs to be supported financially and administratively by government authority. They both influence education, societies and consequently individuals and group behaviour as well. It is very important here to distinct distinguish between these two terms "language planning and language policy" at the basis on their direct relation with Arabicization. Haugen (1968) clarifies language planning as "an activity preparing a normative orthography, grammar, and dictionary for the guidance of writers and speakers in a non-homogeneous 
speech community" (p. 673). Sudan could be considered as "non-homogeneous" as it has different speech communities. According to (Siddiek, 2010), Sudan is a multicultural and multilingual country. We can just contemplate on the following data, that the population of the Sudan according to the ethnic census of 1956 gives us the following information that: the population of Sudan consisted of: 39\% Arabs, 30\% Southerners, 13\% Westerners, $6 \%$ each of Bejja and Nuba 3\% Nubian, 3\% Foreigners \& Miscellaneous. These percentages were based on the identification of tribes (of which 597 were registered, grouped into 56 major tribal groups).

Therefore, Arabicization could be a solution to put all the communities under the umbrella of Arabic language as a Lingua Franca. Conversely, Cooper (1989) refers language planning to "deliberate effort to influence the behaviour of other with respect to the acquisition, structure, or functional allocation of their codes" (p. 45). In this definition Cooper locates language planning as a thoughtful decision needs collective effort in order to achieve its aim, change the behaviour of others (education) for individuals, groups or communities and development and future opportunities for them (functional allocation codes). This emphasized by Robinson (1988, Online) as he declares "official, government-level activity concerning the selection and promotion of a unified administrative language or languages. It represents a coherent effort by individual, groups, organizations to influence language use or development". Consequently, education and language are necessary pillars needed for the development of people and the state equally. Watson-Gegeo \& Gegeo (1990) mark the relation between education and language, "involve significant outcomes for people's lives and futures" (p. 59). Meanwhile language policy defined by Crawford (2003, Online) as:

(1) What government does officially- through legislation, court decisions, executive action, or other means to:

(a) determine how languages are used in public contexts,

(b) cultivate language skills needed to meet national priorities, or

(c) establish the rights of individuals or groups to learn, use, and maintain languages.

(2) Government regulation of its own language use, including steps to facilitate clear communication, train and recruit personnel, guarantee due process, foster political participation, and provide access to public services, proceedings and documents'. From this definition we can say that language planning and language policy complete each other in terms of aims, objectives and goals. Both are done by the governments which support other policies that seek peace, effectiveness and prosperity of the country and nation. Moreover, Emenanjo (2002) illustrates language policy as "a language policy is a policy about human language, its status, its use and usage and its overall management in any polity. It is a policy about who uses or adopts what language, when, where, why and how, in any polity no matter its ethnic or racial make-up; its linguistic composition or ideological position, or its political evolution. Ideally, a language policy should be the end product of language planning informed by, among other things, linguistic data from socio-linguistic surveys or profiles" (pp. 16-20). Here Emenanjo (ibid) gives a detailed definition of language policy, in addition to its relation with human, religion and race. Emenanjo (2002) also cleared up the relation between language planning and language policy as the former flattens to the latter in a consistent relation.

Language planning and language policy played substantial role in all the periods Sudan came through till now. In Sudan there are many dialects, various domestic languages beside Arabic and English. These languages and dialects influenced by many factors. As a result of the different planning of language and policies through the different periods Sudan had passed by, Arabic spread out due to the spreading of Islam especially before and after the Turkish Egyptian rule. This spread was opposed by the colonial rule (British-Egyptian rule).

\subsection{A Historical Look}

In Sudan Arabicization took place over many centuries since the first friction between Arab Muslim and Nubia in 651 CE (Hasan, 1967). Sudan was colonized by Turk-Egyptian in 1821. This colonial period was ended by the Mahdist revolution in 1885.Then the British-Egyptian Rule took Sudan from 1898 till the independence in 1956. All these stages of colonialism influenced education largely specially the language that was used as a medium of instructions (Suliman, 2004). The medium of instruction language during the Turkish was Arabic and this continued during the Mahdist but was disconnected by the British Rule who used segregation policy to divide the county into two regions North and South Muslims VS non-Muslims, Arabs Vs Africans.

In the North they offered modern education and used English as a medium of instruction in secondary schools, for all subjects except religion and Arabic. Meanwhile the medium of instruct in the South was English in governmental and missionaries schools. They thought that using Arabic would help in spreading Arabization and consequently help spreading Islam in the south (Tucker, 1934). But despite all those efforts to institutionalize English, the Governor General lamented by saying in (1927) that "I have fully appreciated the difficulties of ever 
making English the lingua franca of the South. Things have gone much further than I had expected. Whenever I penetrated to the top of the Imatong or the Belgium Congo border, I found Arabic in ready use by the local spokesmen of the people. I need not enumerate the main causes which have operated to produce this result ...we have to consider the very carefully how far it is worth effort and money to aim at the complete suppression of Arabic" (Siddiek, 2010).

So and in spite of all the precaution taken by The British, Arabic became a lingua franca among the tribes in the South due to Muslims soldiers in the British army and the Arab merchants, who used a modified variety of Arabic later known as (Juba Arabic). This spread of Arabic made the ruler worried about the spread of Arabic and consequently Islam (Alsayyed, 1990).

A conference was held in the South in (ArRajaf, 1982) decided to use the Latin alphabet as a solution for the diversity of languages there in an attempt to stop the spreading of Arabic and Islam (Wagi'alla, 1996). However, "the conflicts in education during 1930s would appear to have been about the "wrong" things. Clearly, Arabization should have been allowed to have progressed naturally, and the Arabic language introduced in school at an earlier date", this was stated by Sanderson as she uses "wrong" to indicate wrong decision of choosing Latin alphabet (Suliman, 2004). After the decision of Independence, and the South appended to the North, the educational system integrated, the South with the North. Some Southerners joined College of Gordon in Khartoum (Sudan Government, 1945). After 1948 Arabic became the medium of instruction in the South. In 1949 Juba Publication Bureau began to produce textbooks in Arabic (Sudan Government, 1946, cited in Sanderson, 1975).

The Graduate Congress asked for Arabic to be the medium of instruction in the South. The Legislative Assembly announced Arabic as the language of education all over the country (ibid). An international committee was formed to review education in the Sudan. Three years later in 1975 the international committee recommended Arabic to be used in the primary schools, then intermediate as Arabic was known for most tribes in the South and after 7 years it was used in secondary schools instead of English (Ministry of Education, Sudan,1975). In 1972 Arabic was announced as the official language of the whole country according to Addis Ababa agreement between (southern Sudan rebels and the government (Allair, 1993). In 1998 the Constitution declared Arabic as the official language (Sudan Government, 1998). In 2005 according to the peace treaty between the government and Sudan People's Liberation Army (SPLA) proclaimed English and Arabic as the official languages of the country and the higher education (Sudan Government, 2005). In 1983 Khartoum witnessed the first conference of Arabic language (Miniminah, 2001). In 1990 a symposium was held to discuss Arabic in high education (University of Khartoum) in which a review was recommended for curriculum, textbooks, educational aids and general education goals, beside teachers' training and development (Tamim,1997, cited in Suliman, 2004).

For the Higher education, Arabic was the medium of instruction in the University of Cairo-Branch of Khartoum that followed the Egyptian system of Education. Then the University of Omdurman followed. Other universities changed their medium of instruction from English into Arabic according to the Arabicization policy announced by the Salvation Government. Consequently, all the media (Radio, TV, Newspapers and Magazines) turned to use Arabic (Suliman, 2004). In 1990 came the Higher Education Revolution. One of its aims was Arabicization. It was a political decision apart from academic situation and environment (Gasim, 2010). It was a haste stage as universities lacked textbooks and references in Arabic and even some of the academics staff needed to be trained to teach in Arabic (ibid).

In the thirties when the Graduate Congress formed the idea of arabicization came up. Arabicization in 1948 raised by the legislative committee and Arabic became the official language (Gezira University, 2002). Moreover, after independence in 1957 Arabic was suggested to be used in higher education. In 1970 Arabic was progressively imposed instead of English, officially and academically at universities according to a recommendation made by a ministerial committee recorded that as a result of increase of Sudanese staff at the University of Khartoum it became easier to use Arabic in administration (Wagi'alla, 1996). In 1988 the Arab Health Ministers' council announced the beginning of Arabicization process in all medical and hygienic colleges all over the Arab world. Furthermore, the Arabic conference in 1983 which was held for evaluating Arabic language became another reason that helped in adopting Arabicization. Consequently, the Sudanese Arabicization High Commission had been established (Suliman, 2004). In 1990 Arabicization was taken to be an entity, educational necessity and independence as it was discussed in the four days workshop held at Khartoum University. There also emerged that Arabicization would help the country progress. It would also help in developing the relationship between researchers and students and strengthen the national identity (Sudan government, 2001). 
For tertiary education, all universities were asked to set up a board for implementing the policies of Arbicization. In 1994 the seventh Arabicization conference was held in Sudan. It confirmed the use of Arabic in science, education and media. These conference recommendations asked to be mandatory in all Arab world governmentally and educationally (Miniminah, 2001). Accordingly, there were some steps taken to reinforce the implementation of the Arabicization process. For example, the exchange of visits those run between the Arab medical colleges staff (Suliman, 2004). Furthermore in 2002 a conference was held to evaluate the arbicizing experience at Gezira University (Gezira, 2002). Finally in a report released by Sudan embassy in South Africa summarized the stage that Arbicization has applied in Sudan as it declares: "The Arbicization process has now covered all the states run higher education institutions except few faculties of applied sciences in only two universities where work is underway to complete Arabicization in the near future" (Sudan Embassy in South Africa, 2004).

\subsection{The Dominance of the English Language}

The dominance of English language is increasing day by day all over the world in the major fields, particularly in sciences and researches. One of the most important fields in which English is used, is in the field of Education. The English language was used in schools and administrations by the British colonialists, in both north and south of Sudan that was for elites. But after Independence (1965), the language of instruction was changed into Arabic according to the suggestion of the Sudanzation Committee (Arabab, 2012).

Consequently, many studies showed that as a result of Arabicization deterioration of English standard happened at the tertiary level. This deterioration gave researchers the opportunity to investigate the problem. One of these studies was a project named (The study Habits Research Project) carried out in 1976/77 at the University of Khartoum. Focusing on the Linguistics part of the project; Douglas (1986) stated the relation between language (Arabic-English) proficiency of the two languages (Arabic and English) and the academic performance. Douglas found that the English proficiency level was influenced by the Arabicization of secondary schools. This was also confirmed by Hadra (1990) that English level was partially influenced by Arabicization. Andrews (1984) supported the view that Arabicization has an effect on the English level.

In 1990 Taha drew the attention to the policy of Arabicization at Khartoum University. In Taha's investigations, $81 \%$ of the teachers said that Arabic as a medium model is easier for the students to get into the curriculum content, in addition to $73 \%$ students agreed with their teachers. Moreover, the Arabic as a medium of instruction witnessed an increasing increase in the students' achievement level. To sum up Taha's investigation overall, a positive attitude was given by the participants for the policy of Arabicization.

On the other hand, according to Taha's study, Arabicization was not seen as suitable for the development of the foreign languages in general and English language in particular. A case study carried out by Al Qurashi (1982) (Saudi Arabia education institutions) investigates the awareness and attitude of the participants towards Arabicization including its problems. The findings of this case study reported that, the richness and capability of Arabic as a medium of instruction was not only discussed by the respondent, but they all supported the Arabicization process.

An explanatory study conducted in Jordan by Abed Al Hag in 1998 measuring the attitudes of the language user towards Arabicization in the context of language planning in Jordan. Significantly, the members of the faculty and the students encouraged proceeding with Arabicization in spite of their realisation of shortage of reference materials. Besides, English could be taught but not at the expense of Arabic as scientific language.

Additionally, another study was conducted in Jordan at Yarmouk University by Zohugol \& Taminin (1984) the answered the question: what were the students' attitudes and views towards English versus Arabic as medium of instruction? It resulted that $77 \%$ of the university students preferred Arabic as a medium of instruction while only $14 \%$ did not prefer.

Alkhouri in 1991 held an experiment at the American university in Beirut. He chose two groups of the students who were randomly submitted undergo to different treatment. The first group used English in a scientific subject meanwhile the second group used Arabic. Accordingly, the students who were taught in Arabic excelled. Furthermore, the same two groups were subjected again to the same experiment which this time measured the groups reading comprehension performance. Again the results showed their good performance in the group that used Arabic rather than English. Nevertheless, from all above revealed a sense of positivity towards Arabicization as a medium of instruction at the tertiary level.

Nevertheless, the Academic Council of the faculty of Medicine University of Khartoum determined to confront the Arabicization decision (Kandela, 1993) and got back to English as a medium of instruction. Kandela (ibid) 
also reported that Tingari, the former vice chancellor of the University of Khartoum encouraged instructing in English and criticised the lack of financial support to enhance the Arabicization policy.

Andrews (1986) sums up that "Although the trends towards Arabicization posed problems, it also helped us by limiting our options and forcing us to make difficult but necessary decisions such as concentration on improving reading skills" (p. 182).

In an attempt to improve positively the students' attitudes towards English as a medium of instruction Kambal (1984) suggested that all Arabs countries should collaborate to solve deterioration of the foreign languages against the Arabicization besides, redefining the objectives of teaching in order to improve the students' achievement in English. Furthermore, Kambal (ibid) supported a gradual change for the medium of instruction from English into Arabic. He reports, "a gradual change is less descriptive and more conductive to better results with minimum cost. This is so because it allows for constant evaluation and revision which may certainly lead to success" (p. 19). I think Kambal's view about the gradual change as showed in this paper revealed that imposing the Arabicization process led to that deterioration of English language in Sudan, in education in general and the tertiary education in particular.

In my opinion Arabicization has two great influences on Sudan, Politically and socially. Politically, Arabicization has always been a political decision as a plan and consequently as a policy. Arabic is branded to Arab ethnicity almost Muslims and represents the majority who have the power. While indigenous languages characterized Non-Arab who contrast with Arab in ethnicity, religion and power (Abu-Manga, 2010). Socially, Arabicization has a strong impact on education that influences individuals, their choices for their future careers and therefore their society. Amazingly, both lines I drew meet at one point which Arabicization. On the other hand, Arabicization as a process started as a movement seeking the identity of the nation.

Nowadays, Arabicization can be counted as an obstacle before economic development and social integrity between the various Sudanese ethnic groups all over the country. It may also be considered as part of the political conflict in Darfur, Blue Nile, and South Kordofan and in North Nubian regions as well, where the local languages are factors of unity and homogeneity.

\section{Arabicization as a Project in-Process}

Abdelhay, Eljack, Mugaddam, \& Makoni (2016) wrote a paper under the title of "Arabicization and the Khartoum Arabic Language Academy". In this paper the authors reviewed the historical and cultural background of Arabicization and its relation to governmental institutions that are concerned with Arabic language. The paper also discusses linguistic ideologies and how it is influenced by religion and heritage. It has got three objectives. The first one is about specific textual practices of representation that fix the "image" of Arabic. The second objective is that cultural policy of Arabicization and less recognition of linguistic resources that influenced dialectically, in relation to the institutional power and subjectivity and their importance in the discursive struggle for recognition. The last objective is the comparison and contrast between the role of Khartoum Arabic Academy and the higher Commission for Arabicization in the Sudan. This study cites the bodies that have taken the burden of Arabic Language and the process of Arabicization. The authors came to the conclusion that Arabicization in Sudan is still a project in process.

\section{Conclusion}

Arabicization took place and influenced education in Sudan before and after Independence up to this recent government. It influenced largely education. The practices of the colonial governments to fight Islam by preventing Arabic language in the South of Sudan; resulted in encouraging Arabicization and the spread of Islam as well. The national governments after independence have taken great interest to adopt Arabicization through many processes and policies that have had a remarkable controversial impact on language polices in Sudan.

\section{References}

Abdelhay, A., Eljack, N., Mugaddam, A., \& Maconi, S. (2016). Arabicisation and the Khartoum Arabic Language Academy. The Journal of North Africa Studies, 21(5). https://doi.org/10.1080/13629387.2016.1215248

Abu-Manga, A. (2010). Challenges to Management of Linguistic Diversity in the Sudan. International Seminar on India and Africa: Partnership for Capacity Building and Human Resource Development. Jawaharlal Nehru University, New Delhi, 9-10.

Al Sayyed, N. (1990). Tarikh alsiyasa wa Ita'liim fi Isudan (pp. 37-55). Khartoum: Khartoum University Press. (The History of Politics and Education in the Sudan)

Al-Abed Al-Haq, F. (1998). Language Attitudes and the Promotion of Standard Arabic and Arabicization. In 
Al-Arabiyya.

Allair, A. (1993). Gadaya al-Harb wa al-Slam fi Janoub al Soudan, Arabic Text (tran. by H. Riyad, Dar-el-Jeel). Beirut, (Issues of War and Peace in Southern Sudan).

Andrews, S. (1984). The Effect of Arabicization on the Role of Service English. In J. Swales \& H. Mustafa (Eds.), English for Specific purposes in the Arab World (pp. 172-183). The University of Aston, Birmingham. Cologne: Rüdiger Köppe Verlag.

Arbab, H. S. (2012). Acentury of English Language in Sudan. Journal of Art, 2(7). Khartoum: Khartoum University Press.

Binson, D. (1988). Language Policy and Planning. ERIC Digest.

Braima, M. E. A. (2017). The role of English under Arabicisation: A case study. Unpublished Ph.D thesis. University of Malaya, Malaysia. Retrieved from http://harvester.um.edu.my/index.php/record/view/4917

Cooper, R. L. (1989). Language Planning and Social Change. Cambridge: Cambridge University Press.

Crawford, J. (2003). Language Policy, Language Policy Web Site \& Emporium. Retrieved from http://ourworld.compuserve.com/homepage/JWCRAWFORD/langpol.htm

Douglas, D. (1986). From School to University: Language Policy and Performance at the University of Khartoum. International Journal of Sociology of Language, 61, 89-122. Egyptian Sudan. Berkeley: University of California Press.

Education. (1955). Khartoum. In Wagi'alla, A. (1996) English in Sudan, in Fisherman et Education in Tropical Africa. Studies on Modem Asia and Africa: George Allen.

Emenanjo, E. N. (2002). Language policies and culture identities, a paper presented in the World Congress on language policies, Barcelona, 16-20. Ethnicity, and Race. African Affairs, 107(426), 21-43.

Gasim, G. (2010). Reflecting on Sudan's Higher Education Revolution under Al-Bashir's Regime. Comparative \& International Higher Education, 2, 50-53.

George Allen \& Unwin Ltd. Seminar. (1990). In Higher Commission for Arabicization. Retrieved from http://www.Sudan (1898-1956). In Brown, N. G. \& Hiskett, M. (1975). Conflict and Harmony.

Gezira University. (2002). Taqueem Tajribat al-Ta'reeb bil-Jamah fi al-Fatrah min 1991-2002, A booklet of Arabicization Conference-August 28th, 2002. Arabicization, Writing \& Publishing Committee, (Evaluating Arabicization Experience in theUniversity From1991-2002). Globalization and the Muslim World: Culture, Religion, and Modernity, ed. Birgit.

Hadra, T. O. (1990). The situation of Teaching English In Northern Sudan: Policies and Constraints. In Sudan Notes and Records, 11, 37-51.

Hasan, Y. F. (1967). The Arabs and the Sudan: From the Seventh to the Early Sixteenth Century. Edinburgh: Edinburgh University Press.

Haugen, E. (1968). Language Planning in Modem Norway. In J. A. Fishman (Ed.), (1996) Readings in the Sociology of Languages (pp. 673-687). Paris: Mouton de Gruyter.

Kandela, P. (1993). Academic Defiance in Sudan. In Lancet, 342(8862), 44. Khartoum: Government of Sudan. Linguistics Series. Cambridge: Cambridge University Press. https://doi.org/10.1016/0140-6736(93)91898-V

Miniminah, K. M. (2001). Al-Mutamrat al-Gomiyah wa al-Wataniyah alti Ogidat htaalan hoi Ta'reeb el-Talim al-Tabi wa tosyatiha wa graratiha. (The Up-to-date NationalConferences held about the Arabicization of Medical Education and their Decisionsand Recommendations.) Retrieved from http://www.acmlnet.org/conf23.htm

Ministry of Education, Sudan. (1957). Report by the International Committee of Education 1955. Khartoum, in Wagi'alla, A. (1996). English in Sudan, in Fisherman et al, Post-Imperial English: Status Change in Former British and American Colonies, 1940-1990, pp. 339-356.

Sanderson, L. M. (1975). Conflict, Education and New Awareness in the Southern Sudan (1898-1956).

Siddiek, A. G (2010). Language Situation in Post-War Sudan. International Education Studies, 3(3). https://doi.org/10.5539/ies.v3n3p79

Sudan Embassy in South Africa. (2004). Education. Arabicization in Higher Education. Retrieved from 
http://www.Sudani.co.za/Education.htm

Sudan Government. (1945). The Administrative Secretary Circular No. 89. Khartoum.

Sudan Government. (1998). The Constitution of the Sudan.

Sudan Government. (2001). Decisions and recommendations of Arabicization.

Sudan Government. (2005). The Draft of Constitutional Text. Retrieved from http://www.Sudantribune.com; sudanhighereducatiion.org/arabic.htm

Suliman, F. I. (2004). Arabicization in Higher Education: The case of Medical Colleges in the Sudan. Doctorate of Education: ProQuest LLC.

Taha, A. T. (1990). The Arabicization of Higher Education: The Case of University of Khartoum. Journal of Multilingual and Multicultural Development, 11(4), 291-305. Tollefson, Power and Inequality in Language Education, The Cambridge Applied. https://doi.org/10.1080/01434632.1990.9994418

Tucker, A. N. (1934). The Linguistic Situation in the Southern Sudan. Africa, vii(1), 28-38. Unwin Ltd. https://doi.org/10.2307/3180486

Wagi'alla, A. (1996). English in Sudan. In Fisherman et al. (Eds.), Post-Imperial English: Status Change in Former British and American Colonies, 1940-1990 (pp. 339-356).

Watson-Gegeo, K. A., \& Gegeo, D. W. (1990). Understanding language and power in the Solomon Islands: Methodological lessons for educational intervention.

Wheeler, D. K. (1966). Educational problems of Arab countries. International Review of Education, 12(1), 330-316. https://doi.org/10.1007/bf01421539

Zaghoul, M. R., \& Taminian, L. (1984). The Linguistic Attitude of Arab University Students: Factorial Structure and Intervening Variables. International Journal of Sociology of Language, 50, 155-179. https://doi.org/10.1515/ijsl.1984.50.155

\section{Copyrights}

Copyright for this article is retained by the author, with first publication rights granted to the journal.

This is an open-access article distributed under the terms and conditions of the Creative Commons Attribution license (http://creativecommons.org/licenses/by/4.0/). 